\title{
Badania warstw malarskich z baraków nr 12 i nr 15 znajdujących się na terenie Państwowego Muzeum na Majdanku
}

\author{
Beata Klimek \\ https://orcid.org/0000-0002-6967-9766 \\ b.klimek@pollub.pl \\ Katedra Konserwacji Zabytków, Wydział Budownictwa i Architektury, Politechnika Lubelska
}

\begin{abstract}
Streszczenie: W artykule przedstawiono wyniki badań konserwatorskich opracowań malarskich z baraków nr 12 i nr 15 znajdujących się na terenie Państwowego Muzeum na Majdanku. Wykonano badania składu malatur pobranych z historycznych elementów drewnianych słupów i paneli wewnętrznych oraz kominów. Przedstawione w artykule wyniki stanowią jeden z etapów prowadzonych kompleksowych badań opisujących rzeczywisty stan techniczny, stopień degradacji materiałów w tym opracowań malarskich oraz czynniki wpływające na zachowanie baraku służącego jako obiekt muzealny dostępny dla zwiedzających. Uzyskane w badaniach wyniki stanowią bazę niezbędnych informacji do opracowania metod konserwacji obiektu. Prowadzone badania i dokumentacja zmierzają do zachowania dla przyszłych pokoleń miejsca pamięci niemieckiego nazistowskiego obozu koncentracyjnego i jenieckiego w Lublinie - miejsce, które było świadkiem tragicznych wydarzeń II wojny.
\end{abstract}

Słowa kluczowe: badania konserwatorskie, wymalowania, baraki, stan zachowania, Majdanek

\section{Wstęp}

Baraki o numerze inwentaryzacyjnym 12 i 15, znajdują się na III polu byłego niemieckiego obozu koncentracyjnego w Lublinie na Majdanku pełniącego obecnie funkcję muzealną. Barak nr 15 to barak typu stajennego (Pferdestalle Type 260/9). Spośród baraków tego typu zachowało się na terenie Muzeum 37 takich obiektów z czego 22 zlokalizowane są w obrębie Pola III. Baraki w tym miejscu zostały wybudowane w okresie od kwietnia do sierpnia 1942 r. W czasie funkcjonowania obozu pełniły one funkcję mieszkalną. Baraki posiadały wydzieloną część sanitarną i kominy pozwalające na zamontowanie piecyków. Drewniane baraki stajenne (Pferdestallbaracken OKH - typ 260/9) montowane były z gotowych elementów, dostarczanych do obozu.

W stosunku do oryginalnego wzoru, baraki w Muzeum na Majdanku nie mają wszystkich elementów konstrukcyjnych. Przy montażu (a być może już przy wykonywaniu) zrezygnowano z rygli do których mocowane były pierwotnie koryta i wiązane konie. W części słupów zachowały się jednak otwory po ryglach co świadczy o tym, że wykonane były one z myślą o przeznaczeniu na stajnie lub wykonanie wiernie według wzoru.

Wnętrze baraku podzielone jest na 18 przegród, które pierwotnie przeznaczone były dla koni oraz na stanowiska techniczne. Do doświetlenia wnętrza służyły umieszczone po obu stronach, pomiędzy dachem niskim i wysokim rzędy świetlików.

Baraki od 16 do 22 pola III zostały zdemontowane przez Niemców w 1944 r. Zrekonstruowane w latach 1947-1949 z oryginalnych elementów oraz fragmentów innych baraków w ramach tworzenia Muzeum na Majdanku.

W dokumentacji archiwalnej obiektów nie ma zbyt dużo szczegółów dotyczących prac prowadzonych przy opisywanych obiektach. Wiadomo jedynie, że układ pola III zrekonstruowano w latach 1947-1949. W 1970 przeprowadzono prace zabezpieczające między innymi impregnację ksylamitem. Do chwili obecnej przeprowadzono prace remontowe większości baraków, w ramach których były one demontowane, wymieniano zdegradowane 
elementy i wzmocniono konstrukcje [D. Olesiuk, 2011, T. Mencla, 1991, M. Grudzińska, 2011, Zachować autentyzm, 2000, M. Czajnik, P. Kozarski, Z. Wczelik, 1980, P. Kozarski, 1997].

Za elementy oryginalne baraku uważa się wszystkie elementy posiadające sygnatury. Spotyka się dwa rodzaje sygnatur: sygnatury literowe i sygnatury literowo numeryczne. Kolor farby użytej do oznakowania elementów jest różny. Głównie spotyka się oznakowanie w kolorze czarnym, zielonym lub czerwonym. Kolorystyka oznaczeń zapewne ma związek z firmą produkująca baraki. Wiadomym jest, że baraki w formie rozłożonej, gotowej do montażu dostarczane były przez co najmniej trzy firmy produkcyjne: Schonbrunn, Stagl i Mayer. Firmy te nadzorowały montowanie baraków na terenie obozu. Teoretycznie zestawiając poszczególne oznaczenia można dokonać złożenia baraku w sposób pierwotny, zgodny z konkretnym producentem. Tak zapewne było w trakcie funkcjonowania obozu. Obecnie jest to mało prawdopodobne ze względu na sposób postępowania z barakami po okresie wyzwolenia obozu. Baraki stanowiące obecnie substancję materialną Muzeum są barakami kompletowanymi z elementów innych baraków. Dodatkowo prowadzone remonty często polegające na wymianie poszczególnych elementów na nowe rozmywają oryginalną strukturę [D. Olesiuk, 2011, T. Mencla, 1991, M. Grudzińska, 2011].

Za jedno kryterium oceny oryginalności danego elementu, głównie w stosunku do paneli ściennych wewnętrznych uważane są warstwy malarskie na powierzchniach desek. Panele ścian baraku po stronie wewnętrznej posiadają tak jak w przypadku konstrukcji nośnej baraku oznaczenia literowe (Ryc. 1) lub literowo numeryczne (Ryc. 2).

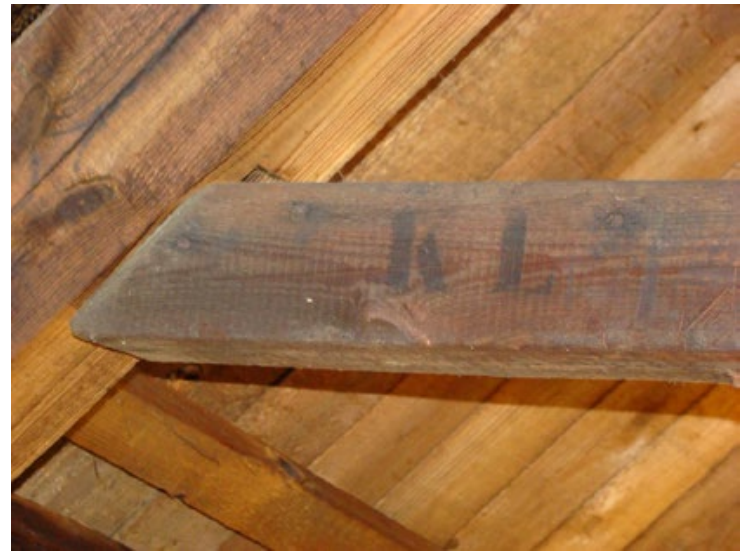

Ryc. 1. Oznaczenie literowe oryginalnego elementu

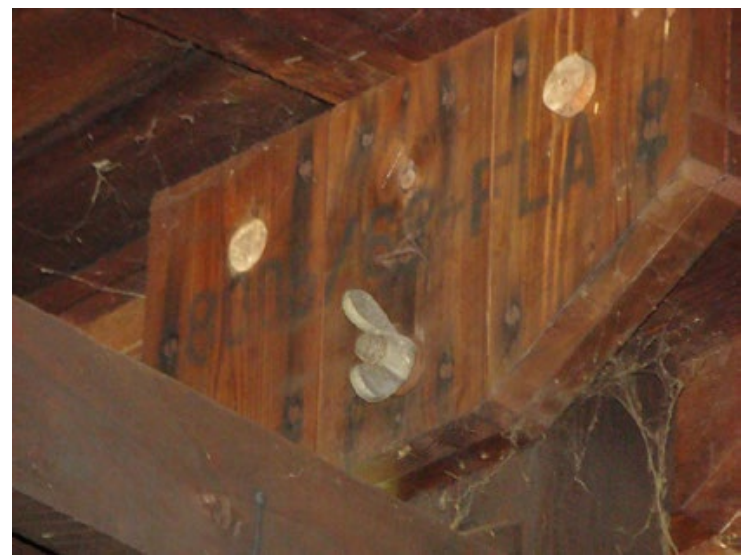

Ryc. 2. Oznaczanie literowo-numeryczne oryginalnego elementu

Często jest jednak tak, że części lub całe powierzchnie paneli są pokryte warstwami malarskimi zakrywającymi Warstwy malarskie napotykane są także na stolcach konstrukcji nośnej bądź w formie lamperii z odcięciem kolorystycznym, bądź w całości są one malowane. W niektórych przypadkach całość konstrukcji nośnej wraz ze ścianami nosi ślady warstw malarskich. Panele z warstwami malarskimi nie są wyznacznikiem charakteru danego baraku. Tak jak w przypadku elementów konstrukcji nośnej najczęściej pochodzą z innych obiektów i są wtórnie montowane w ściany. Jednakże przyjmuje się ich oryginalność za bezsporną [B. Klimek, M. Pytka, 2016].

\section{Badania historycznych tynków i warstw malarskich}

Opracowania malarskie i tynki w barakach w większości przypadków zachowały się, ale są w złym stanie technicznym, miejscami są one bardzo luźno związane z podłożem, łuszczą się i osypują. Dlatego ważne jest, aby te zachowane relikty podać badaniom specjalistycznym w celu ich dokumentacji. Badania zapraw i warstw malarskich prowadzone są przez konserwatorów-restauratorów dzieł sztuki, wspomaganych specjalistycznymi badaniami dla analiz fizyko-chemicznych i badań instrumentalnych. Badania mają na celu rozpoznanie wystroju i historycznej substancji budowlanej pod kątem ich budowy i użytych materiałów oraz faktury, kolorystyki, 
analizy nawarstwień, stanu zachowania i zniszczeń z podaniem ich przyczyn. Celem badań jest przygotowanie wytycznych do projektów konserwatorskich. Badania prowadzone były dwu etapowo:

- badania prowadzone in situ (m.in. odkrywki), w takcie tychże badań typowane były miejsca poboru próbek do badań laboratoryjnych,

- badania laboratoryjne (budowy i składu materiałów): analizy mikroskopowe (elektronowa), analizy instrumentalne (XRD, SEM-EDS),

- analizy opracowań kolorystycznych m.in. malarskich (stratygrafia, spoiwa, pigmenty).

\section{Materiały i metody}

Głównym celem prowadzonych badań było scharakteryzowanie materiałów w wybranych tynkach i opracowaniach malarskich pochodzących z okresu funkcjonowania obozu. W tym celu zastosowano techniki analityczne, takie jak: skaningowa mikroskopia elektronowa SEM z analizatorem EDS i dyfrakcja rentgenowska (XRD). Aby uzyskać maksymalną ilość danych, nie tracąc na poszczególnych etapach cennego materiału badawczego, przyjęto następujące postępowanie badawcze. W pierwszym etapie dokonano szczegółowych oględzin wizualnych opracowań malarskich występujących w obiekcie. Następnie pobrano próbki do badań fizykochemicznych.

Wszystkie metody wymagały pobierania z obiektu niewielkiej ilości zabytkowej substancji. Sama czynność pobrania próbek z dekoracji miała charakter niszczący, gdyż spowodowała bezpowrotną utratę fragmentów zabytkowych zapraw. Wybór właściwych metod badawczych był m.in. związany z ilością dostępnego do badań materiału oraz oczekiwanymi rezultatami.

Każda z technik badawczych (chemicznych, fizycznych, fizykochemicznych) wykorzystywana do analiz zabytkowej substancji wykazuje określone zalety, wady i ograniczenia.

Dyfrakcja rentgenowska stosowana jest powszechnie jako metoda uzupełniająca w badaniach zapraw. Pozwala ona na precyzyjną identyfikację wielu związków o budowie krystalicznej (np. kwarcu, kalcytu, materiałów ilastych). Technika umożliwia przeprowadzenie analiz zarówno jakościowych, jak i półilościowych. Natężenia linii dyfrakcyjnych dla danego składnika mieszaniny zależą od jego ilości w badanej próbce. Badania materiałów zabytkowych wykonuje się na próbkach proszkowych, masy próbek przeznaczonych do analiz wynoszą kilka miligramów. Technika ta dostarcza dużo cennych informacji o strukturze krystalicznej i składzie fazowym materiałów stanowiących budulec zapraw. Technikę wykorzystuje się do identyfikacji kryształów obecnych w próbce i jej składu fazowego poprzez porównywanie uzyskanych dyfraktogramów wzorcami skatalogowanymi w specjalistycznych bibliotekach [M.C. Corbeil, 2004, E. Basiul, W. Bartz, A. Cupa, 2007, J. Rogóż, 2009].

Technika (SEM-EDS) umożliwia wykonanie badań nieniszczących składu chemicznego poszczególnych warstw na przekrojach poprzecznych i powierzchniach próbek polichromii. Mikroanaliza EDS umożliwia stworzenie map pierwiastkowych, obrazujących rozłożenie pierwiastków w badanym obszarze próbki. Wiązka elektronów bombardujących może być kierowana na odpowiedni punkt, precyzyjnie odchylana wzdłuż określonej linii lub skanować wybrany fragment powierzchni próbki. Umożliwia to przeprowadzenie analiz punktowych, liniowych lub powierzchniowych. Analiza powierzchniowa "mapping” ułatwia umiejscowienie stref, w których znajdą się określone pierwiastki, analiza liniowa wskazuje ich lokalny rozkład. Analizy te dają informacje jakościowe i półilościowe o rozłożeniu poszczególnych pierwiastków, zaś analiza punktowa umożliwia ich ilościowe oznaczenie w wybranych mikroobszarach. [E. Basiul, W. Bartz, A. Cupa, 2007, J. Rogóż, 2009, M. Schreiner, M. Melcher, K. Uhlir, 2006, A. Szummer,1994]

\section{Metodyka badań}

Struktury krystaliczne związków chemicznych obecnych w próbkach zapraw badano przy użyciu techniki dyfrakcji rentgenowskiej XRD (X-Ray Diffraction). Analizy XRD wykonywano dla każdej warstwy stratygraficznej osobno. Przygotowanie każdej próbki wymagało rozdrobnienia jej w moździerzu w celu uzyskania drobnego proszku. Próbki proszkowe analizowano przy użyciu dyfraktometru Philips X, PRO typ PW 3040/60, który był wyposażony w lampę rentgenowską z antykatodą miedziową. Warunki pracy były następujące: krok 0,01 czas zliczen $1,2 \mathrm{~s}$, zakres pomiarowy 5-76 ${ }^{\circ}$, 2Theta. Za pomocą analiz uzyskano o informacje o występujących 
fazach i odmianach alotropowych związków występujących w próbkach. Następnym etapem badawczym była identyfikacja pierwiastków występujących w opracowaniach malarskich za pomocą mikroskopii elektronowej z energodyspersyjną mikroanalizą spektroskopową SEM-EDS (Scanning Electron Microscopy-Energy Dispersive X-ray Spectroscopy). (SEM-EDS) przeprowadzono następujących warunkach: przekroje poprzeczne nie były napylane. Oznaczenie wykonano za pomocą mikrosondy elektronowej LINK-ISIS sprzężonej z mikroskopem elektronowym JSM-6300 firmy JEOL (napięcie przyspieszające: 20 kV prąd wiązki: 10-9 A, czas trwania analiz: punkowej $100 \mathrm{~s}$, z mikroobszaru - $15 \mathrm{~min}$ ).

\section{Wizja lokalna i pobranie próbek}

Do badań wytypowano miejsca poboru próbek w baraku nr 15 i w baraku nr 12. Miejsca pobrania próbek ilustrują Ryc. 3, Ryc. 5, Ryc. 7. Wybór miejsc, w których miały być pobrane próbki, był konsultowany przez konserwatora zabytków mgr Michała Pytkę, w sposób umożliwiający analizę wybranych właściwości materiału.

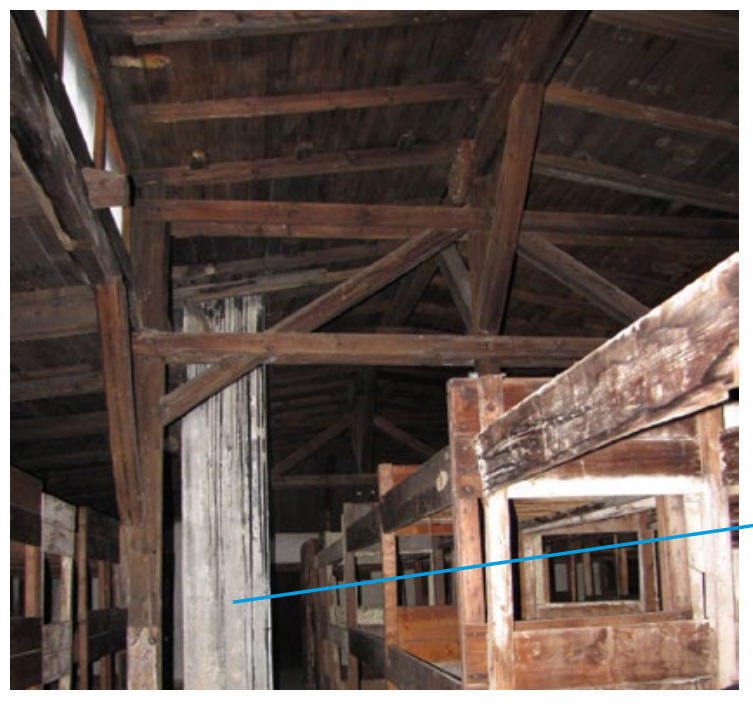

Ryc. 3. Barak nr 15. Komin wewnątrz baraku

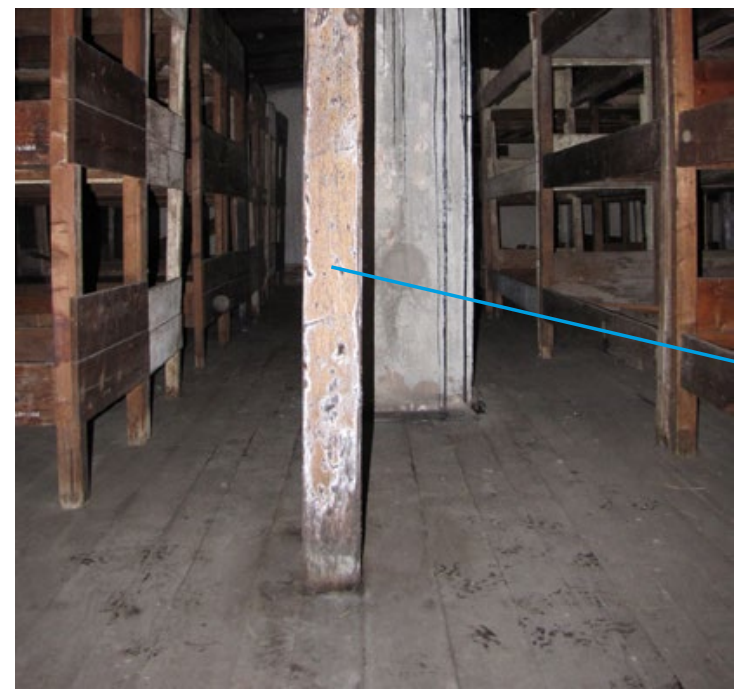

Ryc. 5. Barak nr 15. Słup nr 6
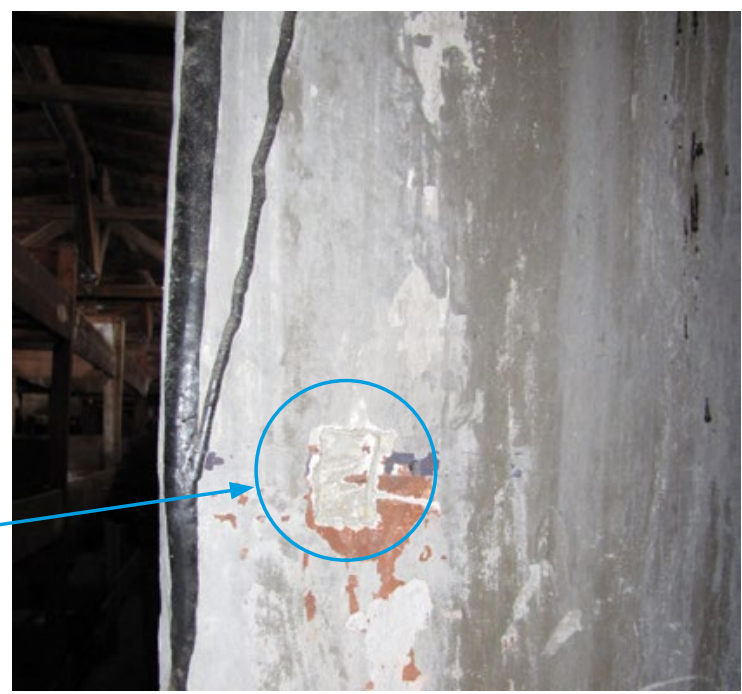

Ryc. 4. Miejsce pobrania próbki P1

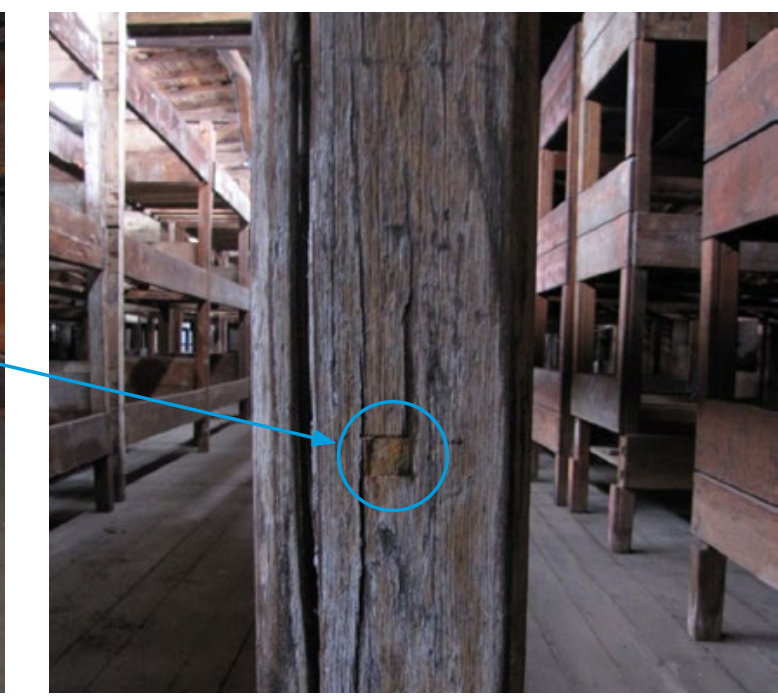

Ryc. 6. Miejsce pobrania próbki P2 


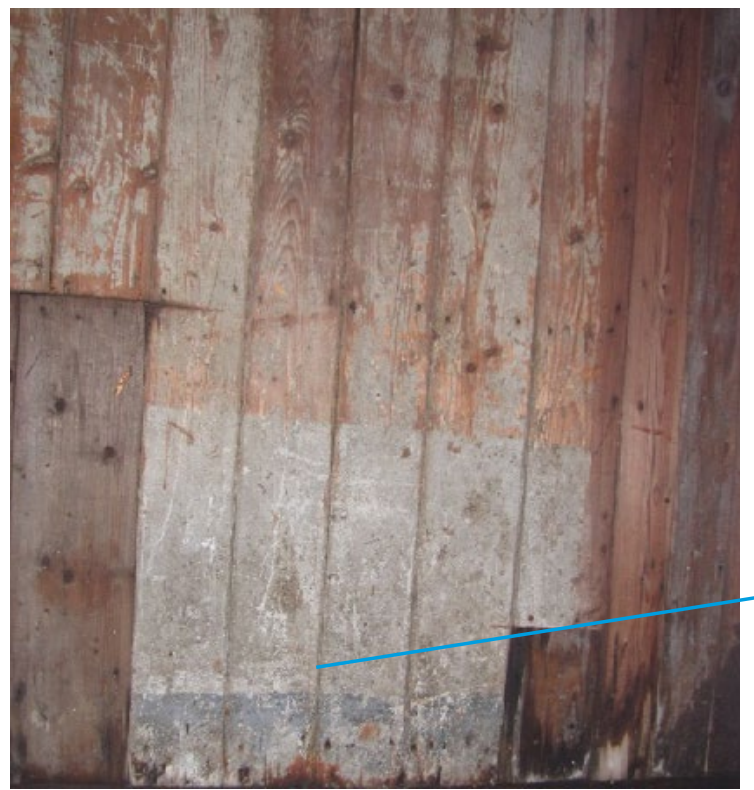

Ryc. 7. Barak nr 12. Panel wewnętrzny

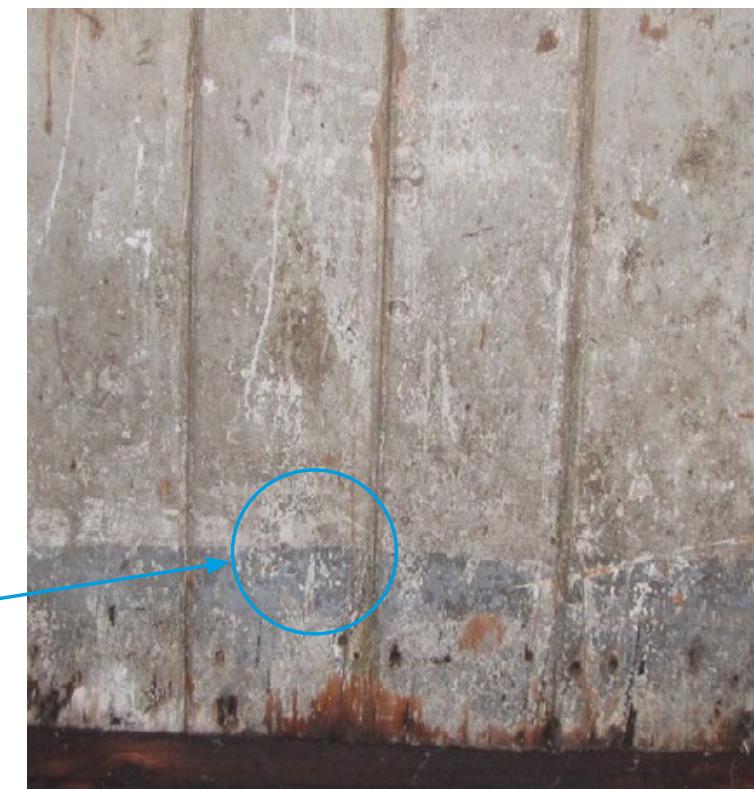

Ryc. 8. Miejsce pobrania próbki P3

Wyniki i dyskusja

Wyniki analizy XRD próbki P1 zaprawy pobranej z komina w baraku nr 15 .

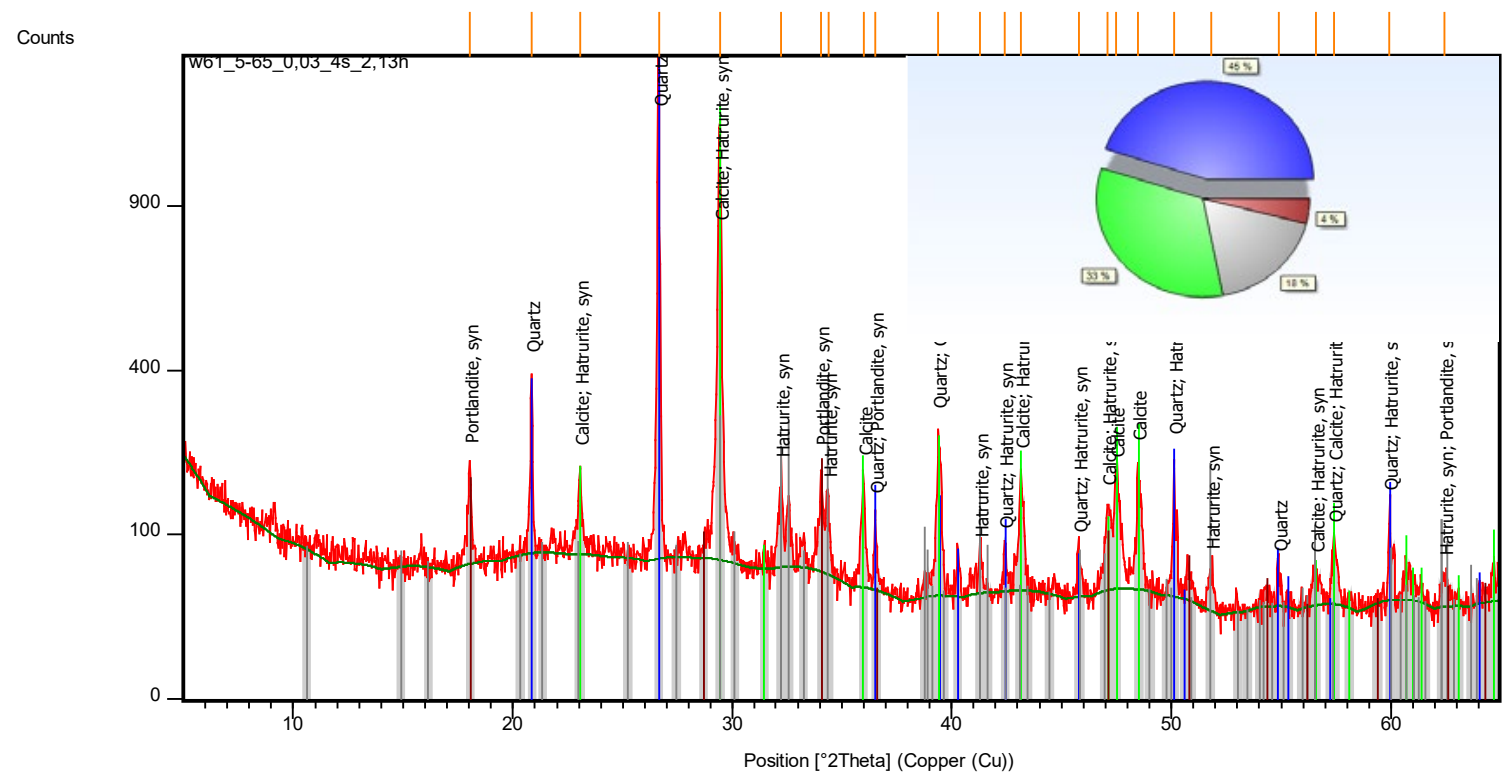

Ryc. 9. Wyniki analizy XRD próbki zaprawy P1: Silicon Oxide - 45\%, Calcium Carbonate - 33\%, Calcium Oxide Silicate - 18\%, Calcium Hydroxide $-4 \%$ ? 


\begin{tabular}{|cccccc|}
\hline Ref. Code & Compound Name & $\begin{array}{c}\text { Displacement } \\
{\left[{ }^{\circ} \mathbf{2} \text { Th.] }\right.}\end{array}$ & $\begin{array}{c}\text { Scale } \\
\text { Factor }\end{array}$ & $\begin{array}{c}\text { Chemical } \\
\text { Formula }\end{array}$ & $\%$ \\
\hline $01-070-7345$ & Silicon Oxide & 0,000 & 1,003 & $\mathrm{SiO}_{2}$ & $45 \%$ \\
\hline $01-075-6049$ & Calcium Carbonate & 0,000 & 0,764 & $\mathrm{Ca}\left(\mathrm{CO}_{3}\right)$ & $33 \%$ \\
\hline $01-073-0599$ & Calcium Oxide Silicate & 0,000 & 0,164 & $\mathrm{Ca}_{3}\left(\mathrm{SiO}_{4}\right) \mathrm{O}$ & $18 \%$ \\
\hline $01-076-0571$ & Calcium Hydroxide & 0,000 & 0,095 & $\mathrm{Ca}(\mathrm{OH})_{2}$ & $4 \% ?$ \\
\hline
\end{tabular}

W otrzymanych dyfraktogramie (Ryc. 9,) najintensywniejsze refleksy pochodzą od tlenku krzemu (\#01-070-7345), który jest głównym składnikiem wypełniacza. Kolejną zidentyfikowaną w tej warstwie fazą mineralną dającą silne refleksy jest węglan wapnia (\#01-075-6049) i (\#01-073-0599) krzemian tlenku wapnia oraz w śladowych ilościach (\#01-076-0571), wodorotlenek wapnia, które to związki wchodzą w skład spoiwa.

Wyniki badań mikroskopowych SEM z energodyspersyjną mikrosondą elektronową EDS (SEM-ESD) malatur pobranych z elementów historycznych z braków nr 12. i nr 15.

\section{Barak nr 15. Próbka P1}

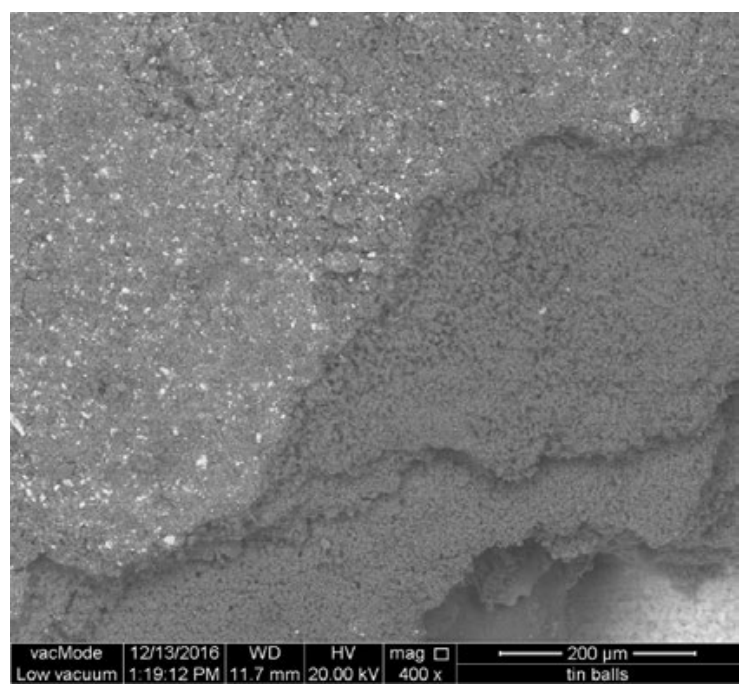

Ryc. 10. Obraz powierzchni próbki P1. W mikroobszarze widocznym na zdjęciu wykonano analizę składu pierwiastkowego. (SEM 400x). Detektor besed

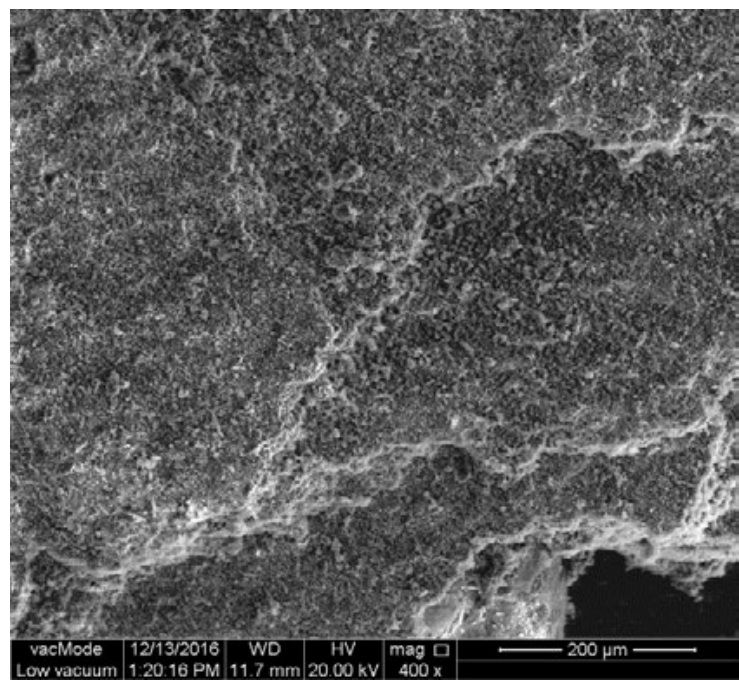

Ryc. 11. Obraz powierzchni próbki P1 (SEM 400x). Detekor set 


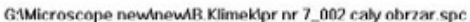

Label A:

\begin{tabular}{|ccc|}
\hline Element & Wt \% & Mol \% \\
\hline N K & 2,33 & 6,78 \\
\hline Mg K & 1,37 & 2,30 \\
\hline Al K & 3,05 & 4,62 \\
\hline Si K & 8,21 & 11,94 \\
\hline P K & 0,22 & 0,29 \\
\hline S K & 5,26 & 6,70 \\
\hline Cl K & 0,75 & 0,87 \\
\hline K K & 1,19 & 1,24 \\
\hline Ca K & 50,23 & 51,17 \\
\hline Ba L & 11,62 & 3,46 \\
\hline Fe K & 13,40 & 3,80 \\
\hline Zn K & 0,87 & 0,54 \\
\hline
\end{tabular}

Ryc. 12. Widmo energetyczne i wyniki analizy EDS próbki P1

Na Obrazie BSE uzyskanym z powierzchni wymalowania na kominie próbka P1 widoczne są drobnoziarniste agregaty (Ryc. 10). Uzyskane widmo EDS (Ryc. 14), wskazuje wysoką zwartość żelaza (13,40\% wag.), co z kolei pozwala wskazać, na tlenek żelaza jako możliwy związek nadający kolor czerwony. Inne pierwiastki to: wapń odpowiada za obecności węglanu wapnia, a także glin i krzem wskazują na występowanie glinokrzemianów.

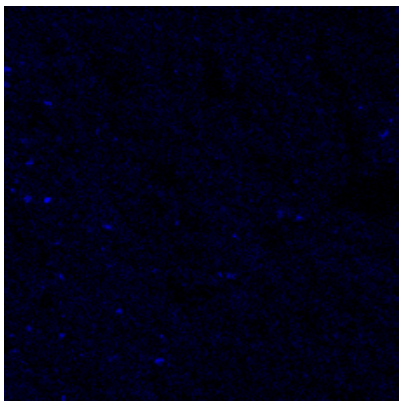

$\mathrm{Mg} \mathrm{K}$

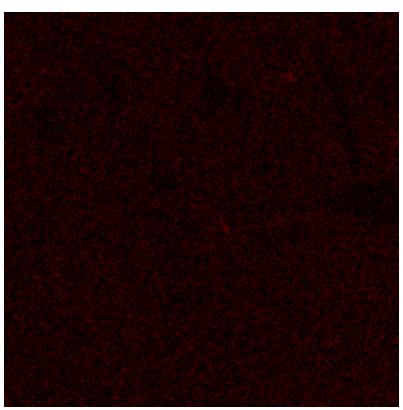

Cl K

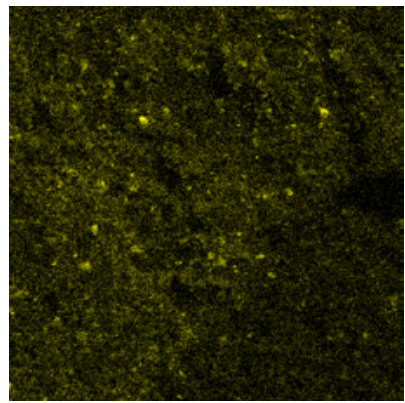

AL K

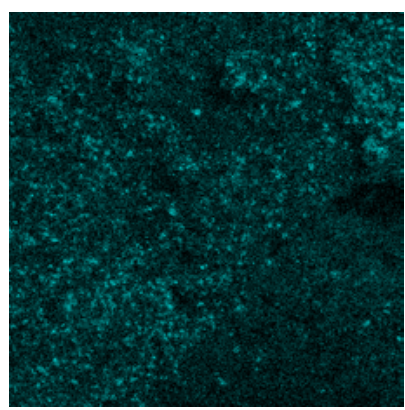

S K

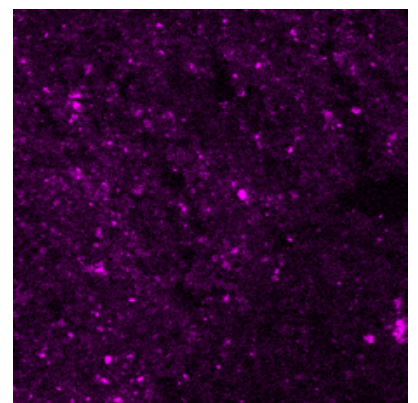

SI K

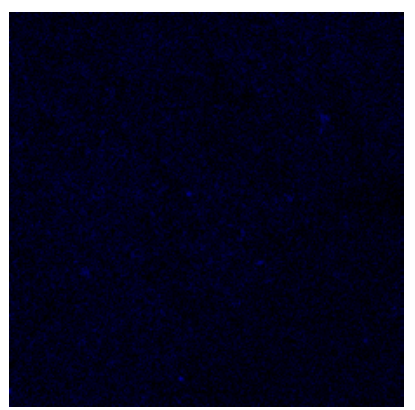

K K 


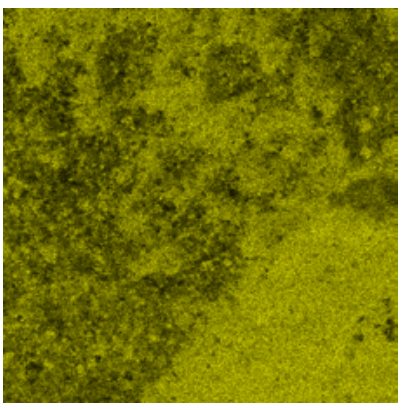

$\mathrm{Ca} \mathrm{K}$

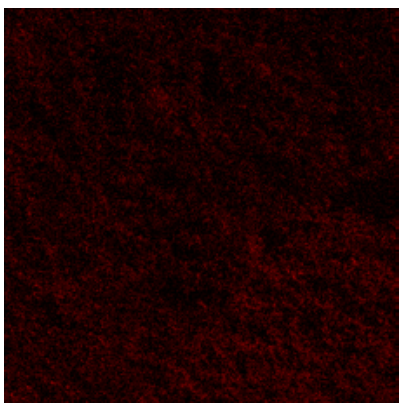

C K

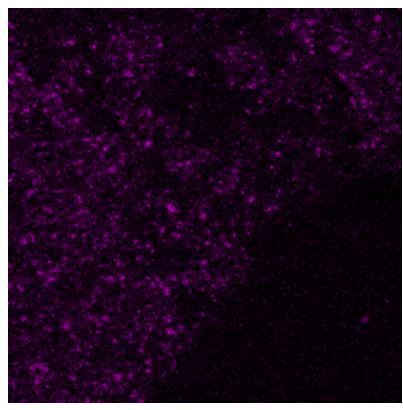

Ba L

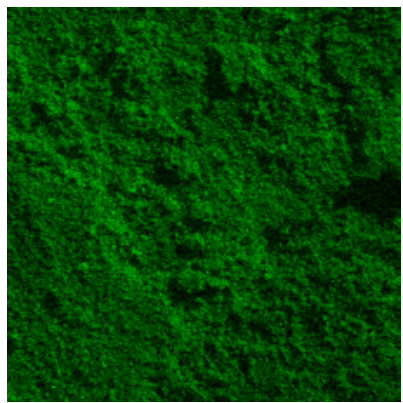

$\mathrm{OK}$

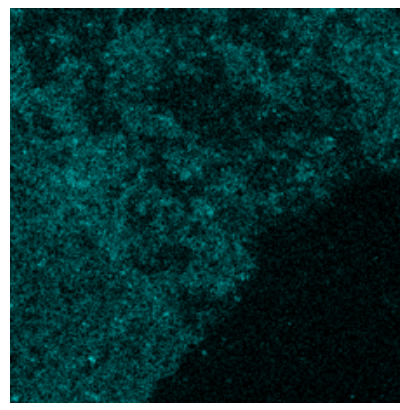

Fe K

Ryc. 13. Mapa rozkładu pierwiastków (SEM-EDS). Wyniki badań próbki P1 wymalowania na powierzchni komina w braku nr 15. Obrazy rozkładu gęstości określonych pierwiastków na powierzchni (SEM-EDS)

Stwierdzono, że analizowany pigment to czerwień żelazowa. Wymalowania wykonano na zaprawie cementowo-wapiennej (analiza XRD, Ryc. 9), kruszywo to piasek kopalniany z okruchami glinokrzemianów i węglanu wapnia, grubości zaprawy 1-2 cm. Na powierzchni malatury wykrystalizowały sole (siarczany i środki do impregnacji drewna).

\section{Barak nr 15. Próbka P2}

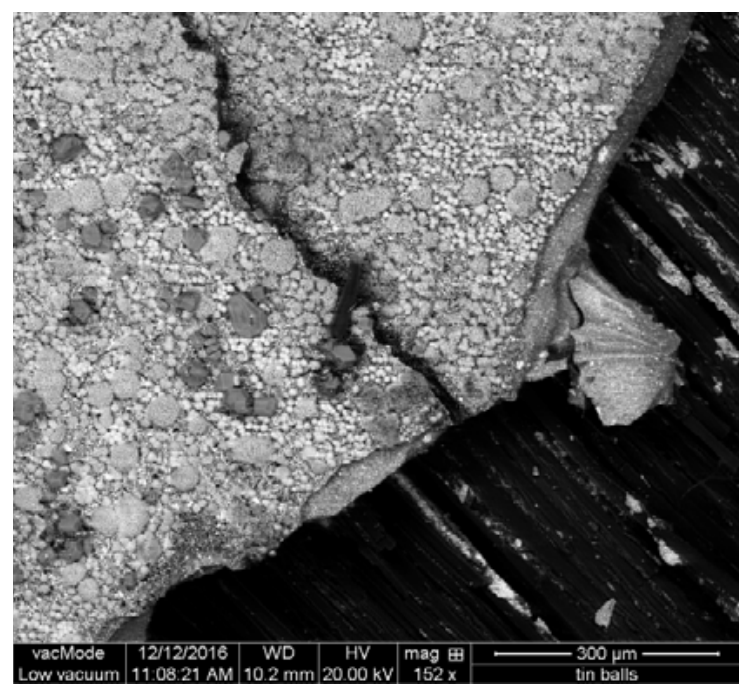

Ryc. 14. Obraz powierzchni próbki P2. W mikroobszarze widocznym na zdjęciu wykonano analizę składu pierwiastkowego (Ryc. 12). (SEM 152x). Detektor besed

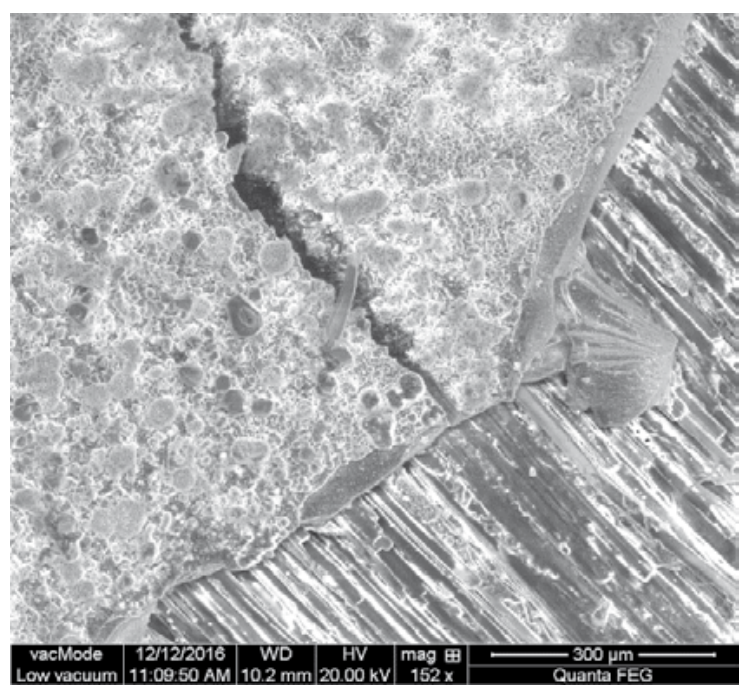

Ryc. 15. Obraz powierzchni próbki $P 2$ z widocznymi wykrystalizowanymi na powierzchni solami. (SEM 152x). Detekor set 


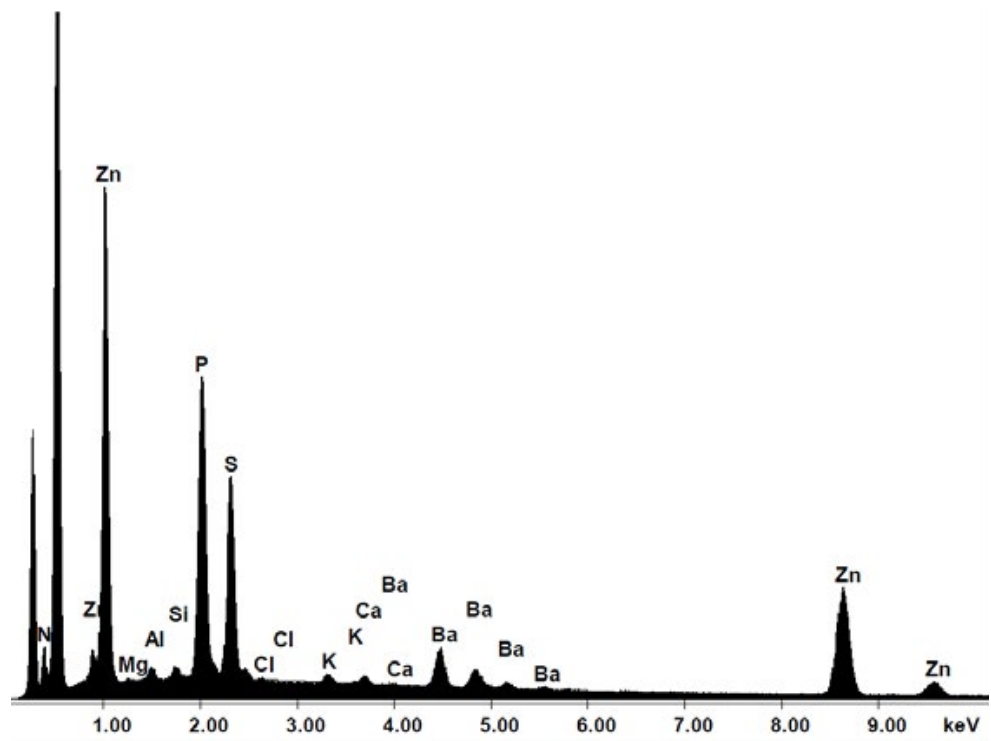

\begin{tabular}{|c|c|c|}
\hline Element & Wt \% & Mol \% \\
\hline N K & 12,60 & 33,55 \\
\hline Al K & 0,93 & 1,28 \\
\hline Si K & 0,76 & 1,01 \\
\hline P K & 17,04 & 20,51 \\
\hline S K & 11,48 & 13,35 \\
\hline Cl K & 0,05 & 0,05 \\
\hline K K & 0,51 & 0,49 \\
\hline Ca K & 0,48 & 0,45 \\
\hline Ba L & 9,86 & 2,68 \\
\hline Zn K & 46,05 & 26,27 \\
\hline
\end{tabular}

Ryc. 16. Widmo energetyczne i wyniki analizy EDS próbki P2

Na obrazie BSE powierzchni wymalowania próbki P2 na historycznym drewnianym słupie, widoczne są rozproszone grube ziarna (Ryc. 12). Mikroanaliza EDS (Ryc. 16), próbki P2 pokazuje występowanie cynku, baru, siarki, fosforu, azotu w mniejszych ilościach glinu, krzemu, potasu, wapnia i śladowych ilościach chloru i żelaza.

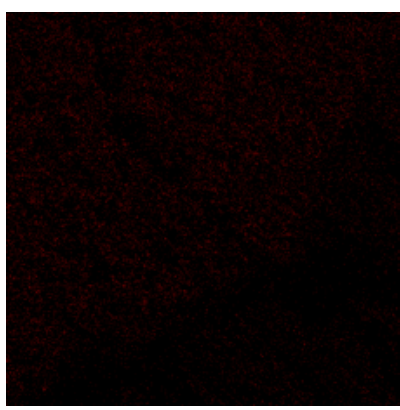

N K

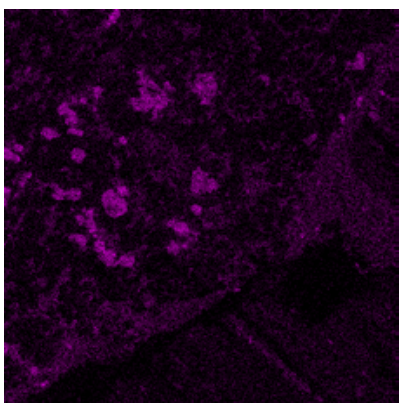

S K

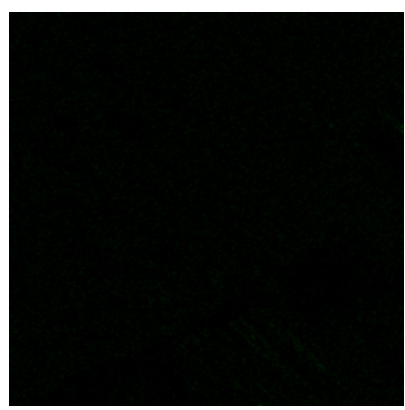

Al K

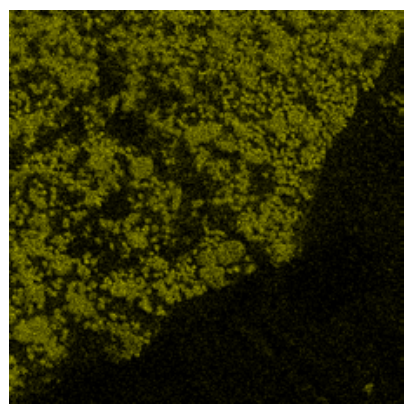

P K

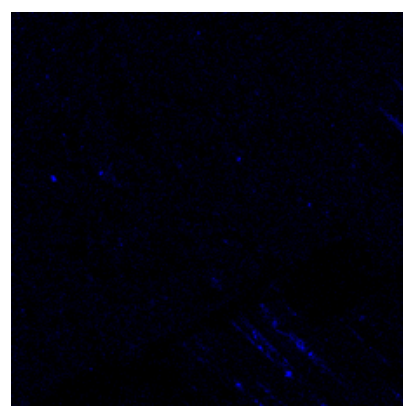

Si K

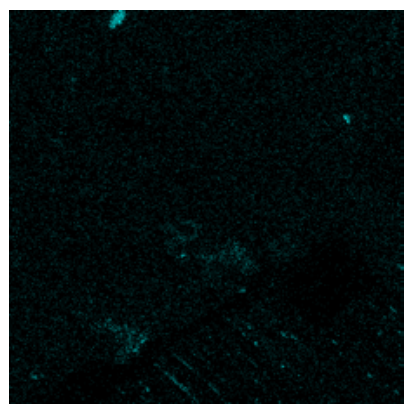

Ca K 


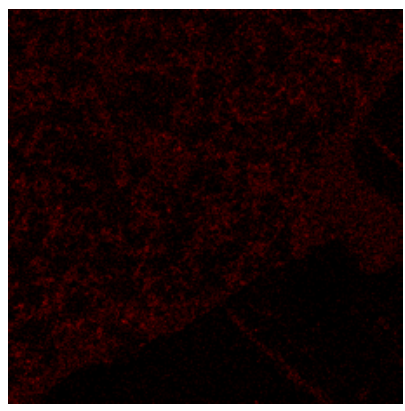

Ba L

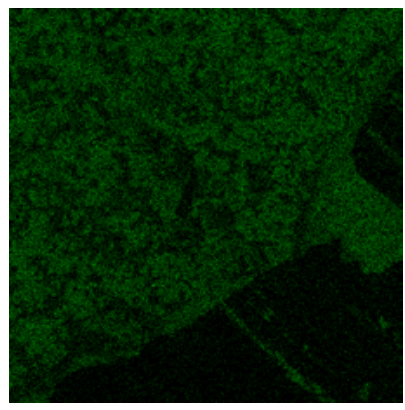

Zn K

Ryc. 17. Mapa rozkładu pierwiastków (SEM-EDS). Wyniki badań próbki P2 wymalowania na powierzchni słupa nr 6 w braku nr 15. Obrazy rozkładu gęstości określonych pierwiastków na przekrojach (SEM-EDS)

Stwierdzono, że analizowany pigment to biel cynkowa, na której powierzchni wykrystalizowały najprawdopodobniej środki do impregnacji drewna. Związki fosforoorganiczne oprócz fosforu zawierają azot, chlor, bar i inne [K. Góralczyk i inni, 2002].

\section{Barak nr 12. Panel wewnętrzny. Próbka P3}

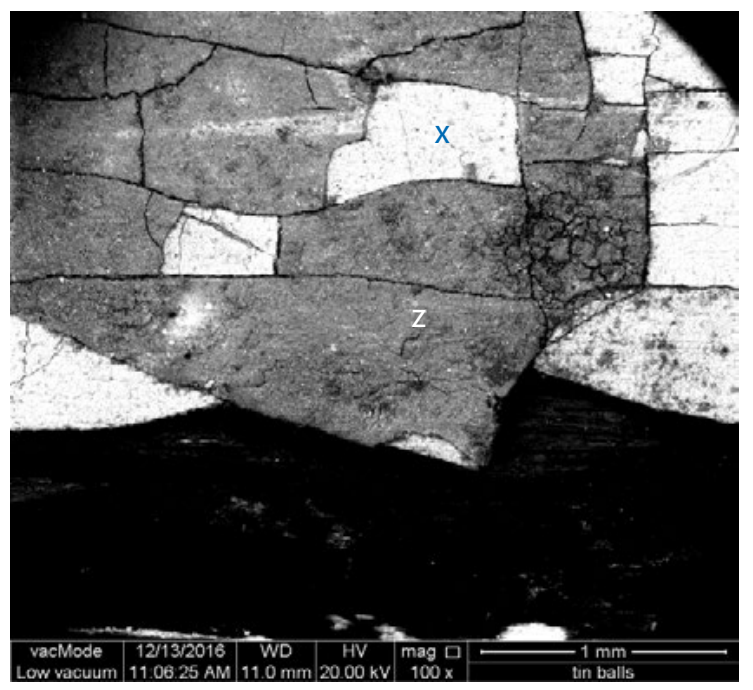

Ryc. 18. Obraz powierzchni próbki P3. W punkcie X i punkcie Z, widocznym na zdjęciu wykonano punktową analizę składu pierwiastkowego. (SEM 100x). Detektor besed

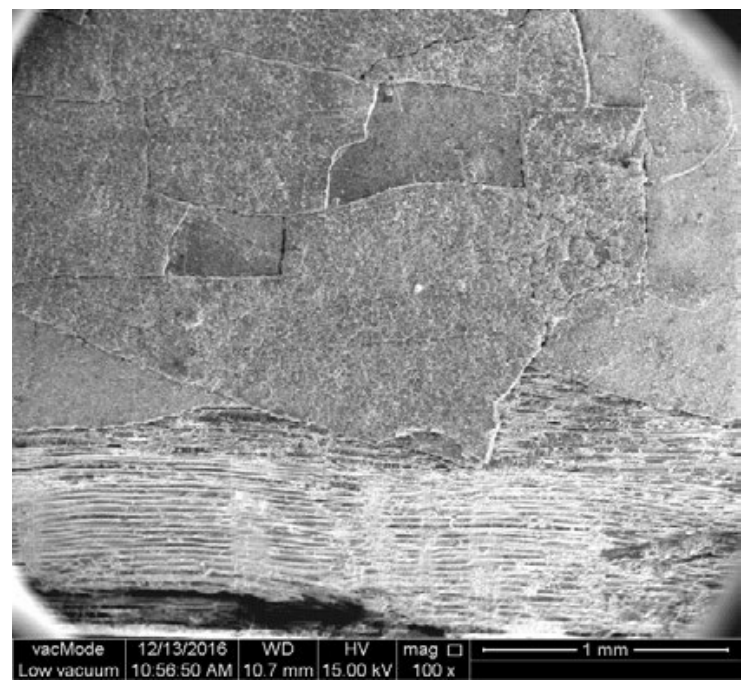

Ryc. 19. Obraz powierzchni próbki P3 (SEM 100x). Detekor set 
G.Microscope newnewB.KlimeKłpr nr 5 majdanek analiza z jasnej powierzchni.spe

\begin{tabular}{ccc} 
Element & Wt \% & Mol \% \\
\hline C K & 14,35 & 36,60 \\
\hline N K & 1,44 & 3,15 \\
\hline O K & 14,36 & 27,51 \\
\hline Mg K & 0,03 & 0,04 \\
\hline Al K & 0,36 & 0,41 \\
\hline Si K & 0,64 & 0,70 \\
\hline P K & 0,13 & 0,13 \\
\hline S K & 12,63 & 12,07 \\
\hline Pb M & 1,84 & 0,27 \\
\hline Cl K & 0,24 & 0,21 \\
\hline K K & 0,14 & 0,11 \\
\hline Ca K & 0,62 & 0,47 \\
\hline Ba L & 27,09 & 6,04 \\
\hline Fe K & 0,53 & 0,29 \\
\hline Zn K & 25,59 & 11,99 \\
\hline
\end{tabular}

Ryc. 20. Widmo energetyczne i wyniki analizy EDS próbki P3, (punkt $X$, jasna powierzchnia na obrazie SEM)

G.Microscope newnewB.KlimeKlpr nr 5 majdanek analiza z ciemnej powierzchni.sp-

Label A:

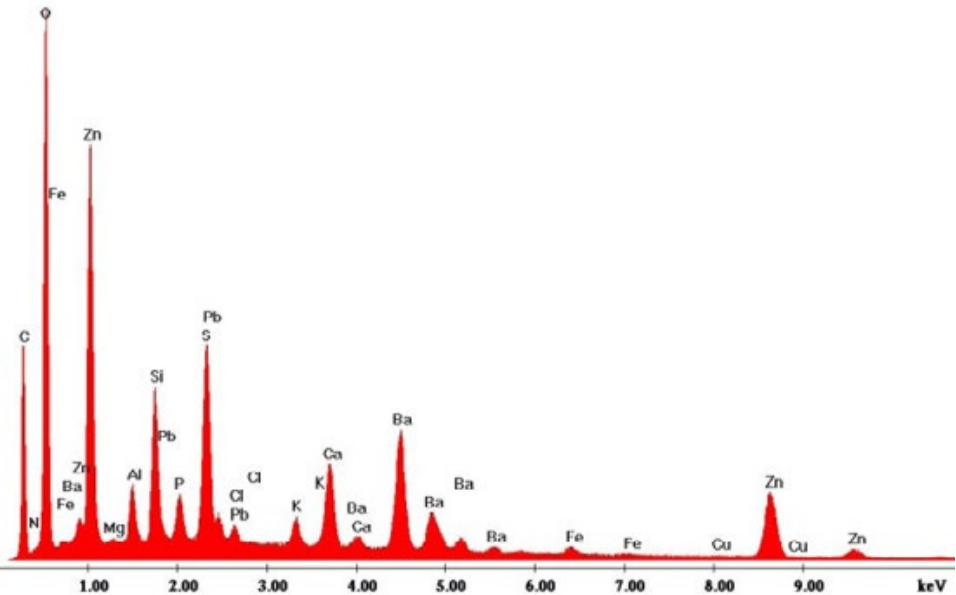

\begin{tabular}{|ccc|}
\hline Element & Wt \% & Mol \% \\
\hline C K & 22,72 & 41,80 \\
\hline N K & 0,54 & 0,84 \\
\hline OK & 27,93 & 38,58 \\
\hline Mg K & 0,11 & 0,10 \\
\hline Al K & 1,59 & 1,30 \\
\hline Si K & 3,97 & 3,12 \\
\hline P K & 1,17 & 0,83 \\
\hline S K & 4,49 & 3,09 \\
\hline Pb M & 2,01 & 0,21 \\
\hline Cl K & 0,45 & 0,28 \\
\hline K K & 0,86 & 0,49 \\
\hline Ca K & 2,84 & 1,57 \\
\hline Ba L & 16,08 & 2,59 \\
\hline Fe K & 0,79 & 0,78 \\
\hline Zn K & 14,53 & 4,91 \\
\hline
\end{tabular}

Ryc. 22. Widmo energetyczne i wyniki analizy EDS próbki P3, (punkt Z, ciemna powierzchnia na obrazie SEM)

Na obrazie BSE uzyskanym z powierzchni wymalowania próbki P3 na drewnianym panelu ściennym widoczna jest spękana powierzchnia, na której wyodrębnić można dwie warstwy (Ryc. 18). Spodnia jaśniejsza punktowa analiza EDS (Ryc. 20, Ryc. 21), z punktu X, wykazała cynk, bar siarkę, węgiel, w mniejszych ilościach żelazo, krzem, glin, azot. Zaś analiza z warstwy wierzchniej z punktu Z wyodrębniła te same pierwiastki, tylko w minimalnie innej zawartości. 


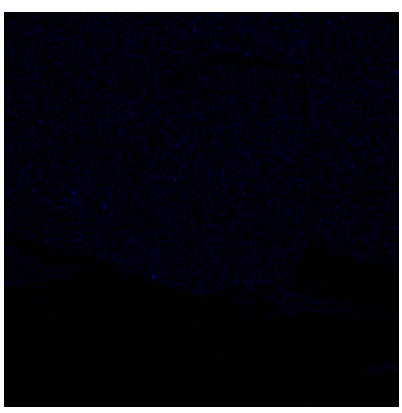

$\mathrm{Mg} \mathrm{K}$

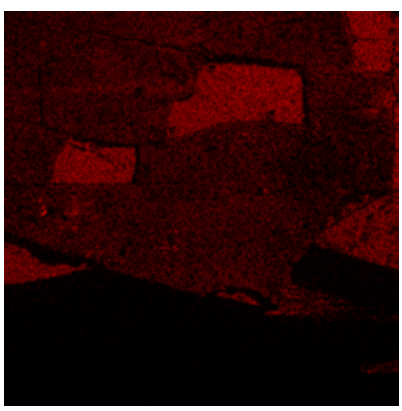

S K

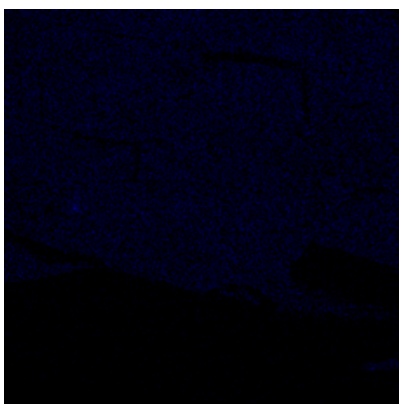

Cl K

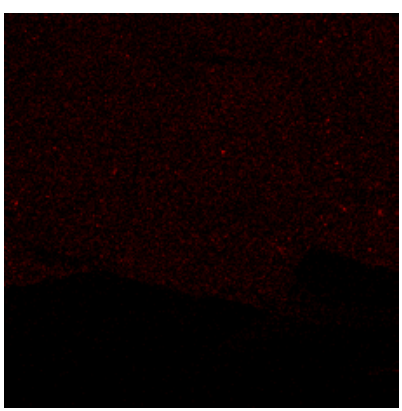

Fe K

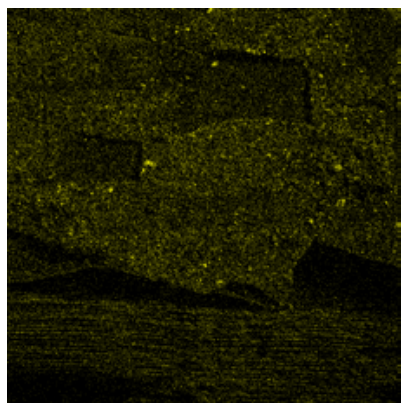

Al K

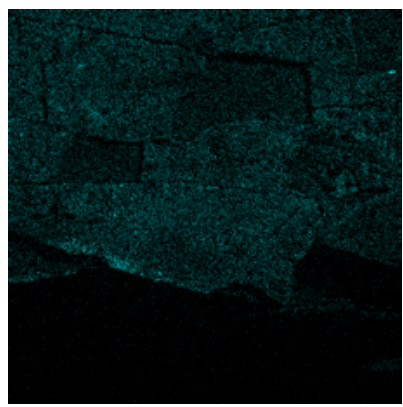

P K

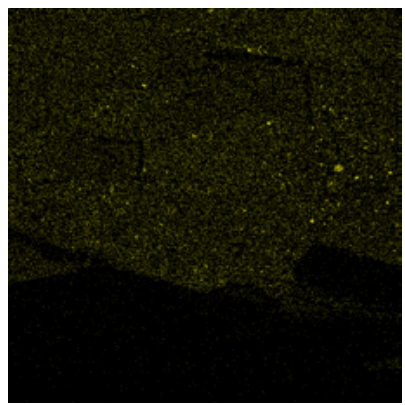

K K

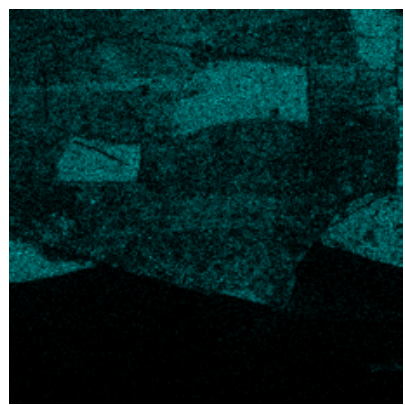

Ba L

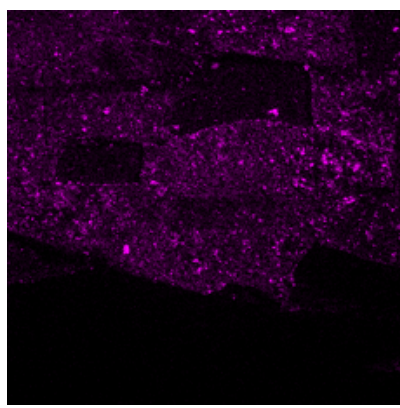

Si K

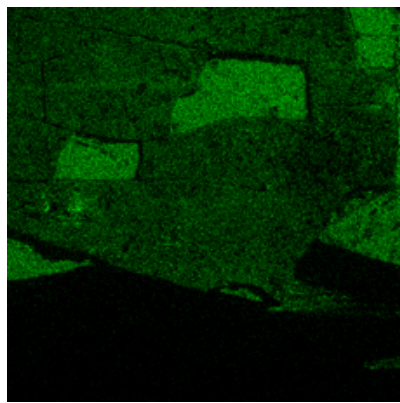

$\mathrm{Pb} \mathrm{K}$

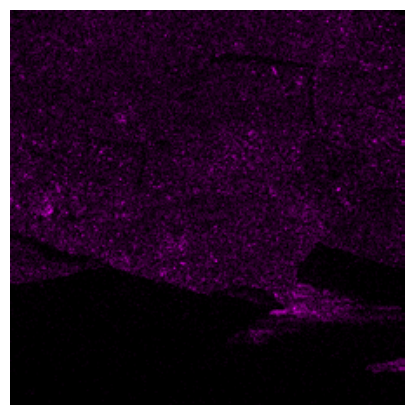

Ca K

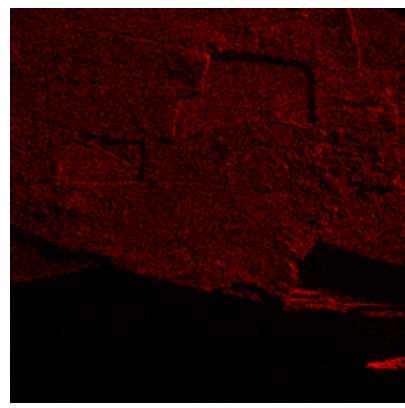

C K 


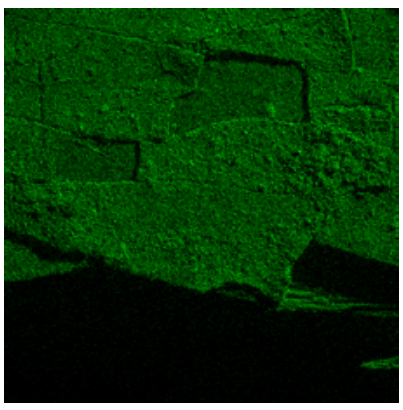

O K

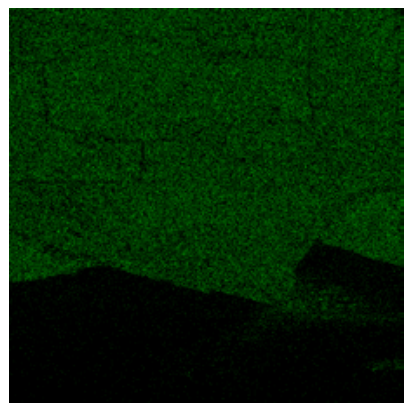

Zn K

Ryc. 23. Mapa rozkładu pierwiastków (SEM-EDS). Wyniki badań próbki P3 wymalowania na powierzchni panelu w braku nr 12. Obrazy rozkładu gęstości określonych pierwiastków na przekrojach (SEM-EDS)

Stwierdzono, że analizowana warstwa w rozbielonym kolorze szaro-niebieskim to: biel cynkowa z dodatkiem błękitu pruskiego, który nadaje kolor. Na powierzchni malatury wykrystalizowały najprawdopodobniej środki do impregnacji drewna.

\section{Podsumowanie}

Obserwacje mikroskopowe i analizy pobranego materiału malatur na drewnie wskazują, że wykonano je w technice olejnej stosując biel cynkową (malatura na słupie barak nr 15). Zabarwienie ugrowe spowodowane jest znaczną warstwą preparatów zabezpieczających.

Malatura na panelu drewnianym z baraku $\mathrm{nr} 12 \mathrm{w}$ kolorze bladoniebieskim to biel cynkowa z dodatkiem błękitu pruskiego. Zabarwienie ciepłe wynika z obecności na powierzchni malatury warstw związanych z późniejszymi zabezpieczeniami. Kontrolne badanie fragmentu drewna na rozkład impregnatu w elemencie wykazało niewielki stopień przenikania w strukturę przypowierzchniową drewna. Na powierzchniach próbek P2 i P3, pobranych z elementów drewnianych, widoczne są sole preparatów zastosowanych do impregnacji drewna.

Wymalowania na kominie $\mathrm{nr} 2 \mathrm{w}$ baraku nr 15 wykonano w technice wapiennej. Warstwa nr 1 jest to tynk cementowo-wapienny z wypełniaczami. W warstwie $\mathrm{nr} 2$ stwierdzono obecność pobiały wapiennej. W warstwie nr 3, którą uznaje się za właściwą warstwę dekoracyjną stwierdzono pigment - czerwień żelazowa oraz spoiwo wapienne. W warstwie nr 4 stwierdzono węglan wapnia oraz sadzę jako warstwę wtórna.

Na próbkach pobranych z elementów murowych komina na powierzchniach krystalizują siarczanowe sole budowlane.

\section{Literatura}

[1] Olesiuk D., Urządzenie przestrzenne Państwowego Muzeum na Majdanku 1944-, Zeszyty Majdanka, tom XXV, 2011.

[2] Mencla T., Majdanek 1941-1944; Wydawnictwo Lubelskie; Lublin 1991.

[3] Grudzińska M., Przewodnik po zbiorze relacji i pamiętników znajdujących się w zasobach Państwowego Muzeum na Majdanku, Państwowe Muzeum na Majdanku; Lublin 2011.

[4] Zachować autentyzm - Konserwacja pięciu drewnianych baraków dawnego KL Auschwitz II Birkenau materiały: www. auschwitz.org/konserwacja/ konserwacja pięciu drewnianych baraków dawnego KL Auschwitz II-Birkenau.

[5] Czajnik M, Wczelik Z., Opinia stanu zachowania obiektów zabytkowego zespołu Muzeum martyrologii w Majdanku.; Majdanek 1980.

[6] Kozarski P., Wytyczne konserwatorskie dotyczące prowadzenia prac remontowo-konserwatorskich w barakach znajdujących się na terenie Państwowego Muzeum w Lublinie na Majdanku; Fundacja Ochrony Zabytków; Warszawa 1997.

[7] Klimek B., Pytka M., Dokumentacja badań warstw malarskich baraków nr 12 i nr 15, na terenie Państwowego Muzeum na Majdanku, Dokumentacja konserwatorska, Lublin 2016. 
[8] Corbeil M.C., Applications of X-ray diffraction in conservation science and Archaeometry, JCPDS-International Centre for Diffraction Data, Advances in X-ray Analysis, 47, 2004, pp. 18-29.

[9] Basiul E., Bartz W., Cupa A., Badania diagnostyczne w konserwacji i restauracji zabytków, [w:] Problemy konserwacji i badań zabytków architektury, prac. zbiorowa pod red. A. Kociałkowskiej, Studzinaka 2007, s. 195-222.

[10] Rogóż J, Zastosowanie technik nieniszczących w badaniach konserwatorskich malowidet ściennych, 2009, Wydawnictwo Naukowe UMK, Toruń.

[11] M. Schreiner, M. Melcher, K. Uhlir, Scanning electron microscopy and energy dispersive analysis: applications in the field of cultural heritage, Analytical and Bioanalytical Chemistry, 387, 3, 2006, pp. 737-747.

[12] Szummer A., Podstawy ilościowej mikroanalizy rentgenowskiej, WNT, Warszawa 1994, s. 61-68.

[13] Góralczyk K. i inni: Uniepalniacze - zastosowanie i zagrożenia dla człowieka. Rocznik PZH 2002, 53 nr 3, s. 293-305.

\section{Research on painting layers from barracks no. 12 and no. 15 located on the premises of the State Museum at Majdanek}

Summary: The article presents the results of conservation research on painting studies from barracks no. 12 and no. 15 at the State Museum at Majdanek. The composition of paintings taken from the historic elements of wooden pillars, internal panels and chimneys was tested. The results presented in the article constitute one of the stages of comprehensive research that describes the actual technical condition, the degree of degradation of materials, including painting studies, and the factors influencing the behavior of the barracks serving as a museum facility available to visitors. The results obtained in the research constitute the basis of the necessary information for the development of methods of object conservation. The conducted research and documentation are aimed at preserving for future generations the memorial site of the German Nazi concentration and captive camp in Lublin - a place that witnessed the tragic events of World War II.

Keywords: conservation research, painting, barracks, state of preservation, Majdanek 